\title{
S. САМОУРАВ/ЕНИЕ
}

Безвиконная Е. В.

\section{МЕХАНИЗМЫ И ФОРМЫ ПОЛИТИЧЕСКОЙ САМООРГАНИЗАЦИИ МЕСТНЫХ СООБЩЕСТВ В СОВРЕМЕННОЙ ЗАРУБЕЖНОЙ ПРАКТИКЕ}

Аннотация: Процессы политической самоорганизации, свойственные современному постдемократическому гражданскому обществу, прежде всего, проявляются в конвенциональных и неконвенциональных формах политического участия граждан в политическом процессе на уровне локальной территории. Указанные механизмы самоорганизации проявляются в политической практике зарубежных государств, свидетельствуя о его переходе на уровень публичного управления как неотъемлимой части современной концепции Governanceуправления.

Ключевые слова: Политология, политическая саморганизаџия, политическое участие, местное сообщество, политический процесс, публичная власть, общественные объединения, связи с общественностью, политические институты, политическая культура

Review: The processes of political self-organizations, being typical for the modern post-democratic civil society, are first of all expressed via conventional and non-conventional forms of political participation of citizens in the political processes at the local territorial level. The above-mentioned mechanisms of self-organization are present in the political practice of foreign states, showing their transfer to the level of public management as an inalienable part of the modern governance concept.

Keywords: political science, political self-organization, political participation, local community, political process, public government, social organizations, public relations, political institutions, political culture.

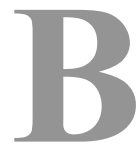

процессе складывания современного постдемократического общества в зарубежных государствах актуализировалась задача поиска адекватных способов выражения общественного мнения по ключевым политическим и социальным вопросам. Политическое участие граждан в рамках новейшей концепции good governance должно перейти с профессионального уровня на все- общий гражданский, предусматривающий вовлечение значительной части населения в решение ключевых вопросов развития политической системы. Неспособность государства сформировать механизмы политического участия граждан влечет за собой нарушение баланса между конвенциональными (законными и общепринятыми) и неконвенциональными (незаконными, противоречащими социальным 
нормам) формами политического участия в пользу последних. Наиболее показательным примером изменения направленности форм политического участия, в европейских государствах стали так называемые «новые альтернативные социальные движения». Данные движения отличаются стихийным характером, отсутствием постоянного членства и внутренней структуры (например, неоднократно проявившее себя участием в насильственных акциях, движение «Оккупируй Уолл-стрит»). Круг вопросов, решаемых новыми движениями достаточно разнообразен, но, в первую очередь, они касаются поддержки альтернативного стиля жизни (флеш-моб, сетевые сообщества), оборонительных и экологических движений ${ }^{1}$. Достаточно точно направленность альтернативных движений оценил Р. Заргарян: «Политическая культура новых социальных движений - это культура участия, характеризующаяся склонностью к личной политической самодеятельности, непосредственным решением проблем, прямой демократией, отсутствием идеологизированности, антирадикальной склонностью к совместным действиям, высоким уровнем уверенности в собственной компетентности» ${ }^{2}$. Одним из проявлений альтернативных социальных движений стали движения протеста «реальная демократия», охватившие в 2011-2012 гг. сначала Испанию, а затем и страны американского континента. Они отличались активным использованием Интернет-коммуникаций, сетевых горизонтальных структур для распространения идей прямой демократии среди молодежных сообществ разных стран. Начало движению было положено в центре Мадрида 15 мая 2011 г., где

\footnotetext{
${ }^{1}$ Подробнее об альтернативных социальных движениях на сайте: http: www.euroalter.com/ppp/ (Дата обращения: 20.09.2012)

2 Заргарян Р. Новые альтернативные движения в Европе: кто они и чего хотят? / Р. Заргарян // Analitica. 25.10.2011.
}

развернулась сеть консультативных пунктов, названных «Генеральные ассамблеи», в которых все желающие могли получить исчерпывающую информацию о возможностях использования механизмов прямой демократии ${ }^{3}$.

Становление альтернативных и городских социальных движений, оборонительных и переходных соседских сообществ, объединенных общностью территории, интересов и целей, свидетельствует о переходе гражданского общества на новый этап своего развития, критерием развития которого становится использование различных форм самоорганизации как вторичной, так и первичной для решения жизненно важных проблем определенного территориального сообщества. В некоторых случаях речь идет о поиске органами публичной власти адекватных механизмов взаимодействия с гражданским обществом, посредством стимулирования гражданско-политической активности или переоценке сложившихся форм прямой демократии 4 .

В отношении нашего исследования наибольший интерес вызывает такая форма альтернативных социальных движений как гражданские инициативы, которые относятся к конвенциональным формам политического участия, как правило, локализованы опреде-

\footnotetext{
${ }^{3}$ Подр. см.: http://www. iri-europe.org (Дата обращения: 13.12.2012)

${ }^{4}$ Одним из последних примеров развития коллективистской модели прямой демократии стал опыт Швейцарии. В результате очередного референдума, проведенного в 2009 г., большинство избирателей высказалось за запрет строительства минаретов, нарушив, таким образом, ключевой принцип европейского сообщества - толерантность. Реакция властей оказалась однозначной - был поставлен вопрос о границах прямой демократии: «Мы придерживались этой формы демократического волеизъявления вплоть до последнего времени. Однако мы все же должны видеть, что и она имеет границы» (Бирюков С. Швейцарский бастион. Прямая демократия против толерантности и мультикультурализма / С. Бирюков // Агентство политических новостей. 20.04.2009 г.
} 
ленной территорией и включают граждан, проживающих на ней. Отличительным их свойством является совместная деятельность по улучшению условий повседневной жизни, отсюда и их название - движения «корней травы» (grassroots) ${ }^{1}$. По мнению Т. И. Макогон, реальное гражданское общество становится возможным исключительно как общность граждан, топологически объединенных в местное сообщество, «в которых на основе гражданских инициатив закладывается фундамент гражданской самоорганизации и гражданского общества» ${ }^{2}$. Гражданская самодеятельность по месту жительства становится в современных зарубежных государствах ключевой формой самоорганизации местных сообществ.

К числу наиболее действенных форм гражданских движений по месту жительства (с точки зрения их способности влиять на принимаемые политические решения) относятся ассоциации (объединения) жителей, проживающих на территории общины. По мнению большинства американских специалистов, именно эта форма социальных движений составляет основу публичной политики, взаимодействия власти и общества: «... те индивидуумы, которые регулярно встречаются на собраниях для обсуждения каких-то волнующих их вопросов, так или иначе обретают навыки совместных действий, становятся субъектами местной политики. Именно на этой почве вырастает то взаимное доверие, которое является основой публичной политики» ${ }^{3}$. Истоки формирования ассоциаций жителей

\footnotetext{
${ }^{1}$ Вагин В. Социология города / В. Вагин http: www. gumer.info/bibliotek_Buks/Sociolog/Vagin/04/php (Дата обращения: 25.12.2012)

${ }^{2}$ Макогон Т.И. Местные сообщества и гражданские инициативы / Т. И. Макогон // Вестник ТГПУ. 2011. № 11 (113).- C. 197.

${ }^{3}$ Civic engagement in American democracy / Ed. By T. Skocpol, M. Florina. Washington: Brookings institution press, 1999.- P. 13.
}

относятся к колониальному этапу складывания американского общества и послевоенному периоду развития европейских государств (1960-е — 1970-е гг.). Так, гражданские ассоциации получили широкое распространение на территории всех английских поселений Нового света, и к началу Гражданской войны второй половины XVIII в. они стали, наряду с иными добровольными объединениями, основой формирования гражданского общества и федеративного государства ${ }^{4}$.

В отличие от европейской политической практики, американская свидетельствует о достаточно широком распространении инициативы непосредственно членов местной общины, которая, получив одобрение на народном собрании, воплощается в конкретном политическом решении. Весьма показателен в этом отношении пример американского города Амхерста, фактически прекратившего свое существование на рубеже 1990-х - 2000-х гг. после закрытия оборонного завода. По инициативе политически активных членов общины (neighborhood community) в корпусах завода был открыт музей, который позволил привлечь средства в местный бюджет и сохранить город 5 . Аналогичным образом ассоциации жителей западных улиц Манхэттена на протяжении 2006-2009 гг. совместно с добровольцами привлекли дополнительные средства, разработали и реализовали проект обновления тротуаров и дорожного покрытия. Достаточно показательным выглядит и пример американского города Кливленда, где действуют около 160 общин в форме добровольных объединений граждан, не предусматривающие их регистрации.

\footnotetext{
${ }^{4}$ См. подр.: Brown R. The emergence of voluntary associations in Massachusetts, 1760-1830 // Journal of voluntary association research. 1973. № 2 (2).- - Р. 64-73.

${ }^{5}$ Кокарев И.Е. Местные сообщества и местное самоуправление: технологии участия / И.Е. Кокарев. М.: МОНФ, 2007. Вып. 63.- С. 23.
} 
Инициатива их создания принадлежала школьным сообществам учащихся, их родителей и администрации, заинтересованных в коллективных усилиях по борьбе с бедностью (малообеспеченностью) и уличной преступностью. Так называемые «социально-активные школы», по мнению президента Кливлендского общественного фонда Э. Уэббера, и стали ядром консолидации городских сообществ ${ }^{1}$. Отличительным их свойством стало решение широкого круга городских проблем, начиная от общей задачи благоустройства территории и заканчивая проведением праздников, увеселительных мероприятий для жителей города. Только при наличии относительно устойчивых проявлений социальной активности граждан на локальной территории орган местного самоуправления (муниципалитет) инициирует реализацию совместных проектов, для обеспечения финансовой поддержки которых создаются общественные фонды.

Подобные общественные фонды созданы во всех городах США, и направлены на вовлечение жителей в совместную деятельность через использование различных каналов коммуникации с местным сообществом. Представляется показательным опыт города Миннеаполис, где сформирована единая сеть коммуникаций, в которые в 2007 г. вовлечены как департаменты и городской совет, так и отдельные общины. В качестве основополагающих принципов формирования культуры политического участия выступают: право на участие в процессе принятия решений всех заинтересованных граждан; индивидуальный подход к оценке потребностей сообщества; поиск заинтересованных граждан и сообществ; предоставление всей необходимой информации участникам; оценка эффекта участия - соотнесение вкла-

${ }^{1}$ Могилевская Ю. «Кузница кадров по американски» (сент. 2012 г.) http: gkhprim.ru/news/interview/kuznitsa kadrov_po-amerikanski/ (Дата обращения: 24.12.2012) да участников и полученного результата 2 . Отличительной особенностью данной формы городских социальных движений является активная позиция муниципалитета в вопросе поддержки общественных и индивидуальных местного сообщества, принятии ежегодных программ участия общин, предусматривающих их целевое финансирование. Увеличение доли участия граждан в политическом процессе связывается с разнообразием способов их воздействия на принятие политических решений. При этом способы стимулирования гражданской активности оказываются достаточно разнообразными, начиная от использования искусства и культуры как средства формирования гражданской гордости и чувства коллективизма (город Мобил штат Алабама ${ }^{3}$ и и заканчивая реализацией совместных проектов муниципалитетов и предпринимателей по предоставлению жилья малообеспеченным семьям, созданию сети мелких бытовых услуг, предоставляющих возможность повысить уровень благосостояния городских общин (город Остин штат Техас ${ }^{4}$ ).

Несмотря на наличие инициатив со стороны некоммерческих агентств, общественных фондов (например Neighborhood community foundation ${ }^{5}$ ) и органов местной власти по оказанию поддержки и стимулированию гражданской активности местного сообщества, деятельность которых зачастую финансируется из государственного или местного бюджетов, и направлена на предоставление помощи населению и их объединениям, население самосто-

\footnotetext{
${ }^{2}$ Neighborhood and Community Relations (NCR) http:// www.minneapolismn.gov/ncr/index.htm (Дата обращения: 24.12.2012)

${ }^{3}$ Neighborhood and community service http://www. ncsmobile.org/about.php (Дата обращения: 12.11.2012)

${ }^{4}$ Neighborhood and community development http://www. austintexas.gov/department/housing/media (Дата обращения: 12.11.2012)

${ }^{5}$ Neighborhood community foundation http://neighborhoodcommunity.org/ (Дата обращения: 12.11.2012)
} 
ятельно выбирает формы и механизмы сотрудничества с ними. Так, в Нью-Йорке действует более 100 общественных фондов, ориентированных на повышение качества жизни населения посредством привлечения инвестиций, пожертвований в развитие территории, оказание помощи нуждающимся гражданам ${ }^{1}$. Из них 12 специализируются на оказании содействия жителям в вывозе мусора и благоустройству пустырей. При их непосредственной поддержке была создана некоммерческая организация «Мы заботимся о Нью-Йорке», которая занимается уборкой мусора и установкой мусорных контейнеров. Добровольцы, участвующие в ее работе награждаются различными знаками отличия (грамотами, значками) ${ }^{2}$. Аналогичную поддержку соседским ассоциациям, занимающимся озеленением, а также реализацией других социальных проектов занимается, и Cornell cooperative extension serves, финансируемая из средств федерального бюджета ${ }^{3}$.

Американский политический опыт самоорганизации городского сообщества определяется наличием разнообразных социальных движений, выступающих за улучшение своей повседневной жизни, быта и повышение уровня благосостояния. Преобладающей формой соседства становятся общественные фонды, движения, а также спонтанные акции, организованные как группами заинтересованных граждан, так и представителями общественных организаций и органов местной власти. В целом, состояние процессов вторичной самоорганизации в США свидетельствует

\footnotetext{
${ }^{1}$ Показателен опыт работы общественного фонда «Хозяйство Бронкса - района Нью-Йорка»: Neighborhood housing services of New York http://www. nhsnyc.org/en/about-us (Дата обращения: 12.11.2012)

${ }^{2}$ Initiatives and funding programs http://www.nysegov.com/ citGuide.cfm? superCat $=396 \&$ cat $=404 \&$ content $=$ main $($ Дата обращения: 12.11.2012)

${ }^{3}$ Cornell cooperative extension http://www.cce.cornell.edu/ Pages/Default.aspx (Дата обращения: 12.11.2012)
}

о переходном характере местного сообщества, для которого характерен средний уровень социальной и политической активности, обусловленной потребностью разрешения конкретной ситуации или целенаправленной политикой некоммерческих организаций.

В отличие от американского опыта вторичной самоорганизации европейский свидетельствует о непосредственном участии органов публичной власти в процессе объединения населения в соседские общины. Потребность обращения к потенциальным возможностям территориальных сообществ возникла в 1960-х гг. в условиях экономического кризиса, охватившего все государства Европы, снижения общественного доверия к политическим партиям и роста массовых движений протеста. Для разрешения социальной напряженности потребовалось изменить направленность социальных движений на решение жизненно важных проблем конкретной территории посредством конвенциональных механизмов. Идеологами формирования концепции прямой общинной демократии стали А. Грамши и П. Фрэзер 4 . Проекты развития соседских общин (Community development projects) получили широкое распространение в 1970-х гг. в 12 городах Великобритании. В первую очередь, они касались организации ассоциаций жителей, собственников жилья или квартиросъемщиков для подготовки и реализации совместных проектов по благоустройству жилых помещений, а также прилегающей территории микрорайона (квартала). Первоначально отдельные инициативы муниципальной власти оценивались жителями в качестве способа получения финансовой поддержки со стороны политических

\footnotetext{
${ }^{4}$ См. подр.: Грамши А. Избранные произведения: [пер. с итал.] / [Под общ. ред. И. В. Григорьевой и др.; Вступит. статья Г. П. Смирнова; Примеч. И. В. Григорьевой, К. Ф. Мизиано].- М.: Политиздат, 1980.—422 с.
} 
институтов, а в дальнейшем они приобрели статус самостоятельного механизма решения проблем жилищного строительства, обслуживания, содержания и благоустройства жилья. В структуру данного механизма входят: ассоциации квартиросъемщиков (жители одного или нескольких домов), микро районные организации (правления, советы директоров) и районные (городские) организации (коалиции, гражданские комитеты) ${ }^{1}$. Наличие внешней инициативы по формированию условий для объединения местного сообщества в общественные организации как институциональной, так и неинституциональной природы, не позволяет оценивать их в качестве формы первичной самоорганизации. Речь идет о вторичной самоорганизации, вызванной влиянием внешних факторов и процессов. С другой стороны, в условиях современного развития европейского общества возможности первичной самоорганизации ограничены мировоззрением индивидуализма, значительным социальным расслоением, недостаточным уровнем политического воспитания и политической культуры, неограниченными ресурсными возможностями государства и иных политических институтов. Общинный сектор, по мнению М. Тэйлора, А. Бара и А. Веста становится необходимым условием интеграции соседских сообществ в процессы планирования и управления территорией, в пределах полномочий, предоставленных политическими институтами르.

В современных условиях сообщества по вопросам развития (CD) представляют собой политическую практику деятельности отдельных лидеров, активистов, граждан и общественных организаций по улучшению

\footnotetext{
${ }^{1}$ См. подр.: Заокеанский опыт. Защита жилищных прав // ТриД (электронный журнал). 2009. № 2.

${ }^{2}$ См. подр.: Taylor V., Barr A., West A. Signposts to community development foundation. N.Y., 2000.
}

различных аспектов жизни местных общин ${ }^{3}$. Данные сообщества ориентированы на объединения наиболее активных граждан, обладающих навыками для осуществления функций организаторов подобных локальных групп (лидеров). С точки зрения британской благотворительной организации - Community Development Exchange современная община представляет собой: «Набор ценностей и практик, которые играют особую роль в борьбе с бедностью и недостатком, объединение общества на местном уровне и углубления принципов демократии. Есть активные граждане, которые используют методы сообщества по вопросам развития на добровольной основе, которые в состоянии выполнить функции его организаторов» ${ }^{4}$. Сообщества развития ориентированы на изменение принципов взаимоотношений между членами городского общества, и направление их на совместные коллективные действия по решению проблем общины. В современной практике существует много примеров функционирования сообществ развития, специализирующихся на решении конкретных задач развития территории, среди них следует назвать Community economic development (CED), Social capital formation, community-based participatory research (CBPR), Community-driven development (CDD) и т.д. ${ }^{5}$ Основной формой деятельности подобных некоммерческих организаций становится реализация различных программ, преимущественно благотворительных, которые призваны через разрешение социально-экономических проблем, повысить уровень политической

\footnotetext{
${ }^{3}$ Ferguson R.F., William T.D., eds., Urban Problems and Community Development. Brookings Institution Press, 1999. - P. 87.

${ }^{4}$ Harris K. Isn't all community development asset-based? // Guardian piece. 23 July. 2011.

${ }^{5}$ Chigbu U. E. Village renewal as an instrument of rural development: evidence from Wryarn, Germany // Community Development. № 43 (2).— P. 209-224.
} 
активности граждан и социальной ответственности бизнеса ${ }^{1}$.

Несмотря на ограниченные возможности такой формы самоорганизации граждан как ассоциации по месту жительства, именно она предопределила превращение отдельных ассоциаций в инициативные движения, выступающие с политическими требованиями и отстаивающие свои права, и интересы на уровне политических институтов. Подобные сообщества ориентированы на защиту места своего проживания от любой внешней угрозы, т.е. носят направленно оборонительный характер. В частности, подобные ассоциации получили широкое распространение на территории сельских приходов Великобритании, что привело к совмещению интересов местной общины и пресвитерианской церкви. Отличительным свойством подобных ассоциаций стало наличие постоянных фондов (организаций) оказывающих финансовую, информационную, консультативную и социальную поддержу разнообразным общественным инициативам или отдельным социальным группам². Оборонительный характер подобных объединений по месту жительства постепенно дополняется целым комплексом дополнительных

\footnotetext{
${ }^{1}$ В частности, подобные цели ставит перед собой крупнейший фонд развития местных сообществ Community development foundation: Community development challenge report/Community development foundation for communities and local government http://www.cdf.org.uk/SITE/ UPLOAD/DOCUMENT/communitydevelopmentchallenge. pdf (Дата обращения: 20.09.2012)

${ }^{2}$ Так, на территории Эбертана (Великобритания) с 2009 г. действует несколько ассоциаций по месту жительства: The fairmead residents association, The south Melton community association, Town center residents group, Sheltered forums, Village voice и др. Для них характерна специализация на решении проблем местных жителей, начиная с организации ремонтных работ и заканчивая охраной окружающей среды и совместной борьбой с преступлениями. См. напр.: Residents Associations http://www.melton.gov.uk/housing/resident_involvement/ residents_associations.aspx (Дата обращения: 24.09.2012)
}

функций и задач, решаемых на локальной территории. Так, Havering residens association первоначально возникнув как объединение жителей города Хэверин для совместного решения проблем безработицы сегодня представляет собой сетевую организацию комплексно решающую различные проблемы территории и реализующую разнообразные программы ${ }^{3}$.

Наряду с конвенциональными формами объединения местного сообщества в зарубежной практике используются различные формы социального, а впоследствии и политического протеста. Один из наиболее громких примеров реакции граждан на ущемление их права на жилище - создание Ассоциации жителей денационализированных домов Варшавы, протестующей против внесения поправок в Гражданский процессуальный кодекс Польской Республики (ст. 620.6), допускающих выселение нанимателей квартир, в случае национализации недвижимости за долги собственника. Основной формой политической активности стали пикеты у здания польского Сейма. Весьма показательна оценка данных акций самими их участниками: «Партии должны отвечать за своих депутатов в Сейме. Помните господа депутаты, выборы не за горами. Мы будем очень внимательно следить за судьбой законопроекта и надеемся, что у вас хватит здравого смысла отказаться от лоббирования интересов банков за счет поломанных жизней людей» ${ }^{4}$. Становится совершенно очевидным четкое понимание организаторами и участниками подобных политических акций степени своего влияния на политические процессы в государстве, которое позволяет им не только выдвигать требования, но и добиваться их

\footnotetext{
${ }^{3}$ Havering residens association http://haveringra.org.uk/ (Дата обращения: 20.12.2012)

${ }^{4}$ Сейм выполнил требование Ассоциации жителей денацдомов и отозвал бесчеловечные поправки // Publica. LV. 5 апреля 2012 г.
} 
исполнения. Аналогичные формы протестной политической активности в условиях распространения сетевых технологий получили распространение практически во всех зарубежных государствах. Аналитики отмечают высокую мобильность и динамизм подобных проявлений гражданской активности, особенно на локальной территории ${ }^{1}$.

Подход государства и иных политических институтов к разрешению возникающих социальных, а в последующем и политических противоречий напрямую обусловлен наличием (отсутствием) развитых механизмов взаимодействия с обществом (его отдельными группами), готовностью к партнерским отношениям со всеми субъектами политического процесса. Особенно очевидным данный вывод становится на примере государств переходного типа, в частности стран СНГ. Например, митинг у здания кабинета министров Украины, проведенный в декабре 2011 г. активистами ассоциации жителей общежитий, включающей представителей 23 общежитий Киева, не привел к разрешению возникшего конфликта, а перевел его в латентную форму. Основное требование протестующих заключалось в передаче общежитий из ведомственной собственности в коммунальную, с целью гарантировать права и защитить интересы их жителей ${ }^{2}$.

Самостоятельное значение среди объединений жителей локальных территорий имеют различные ассоциации, созданные для борьбы с бедностью и различными социальными пороками (наркоманией, алкоголизмом и т. д.). Ключевое значение для их формирования имеют программы по борьбе с бедностью,

\footnotetext{
${ }^{1}$ Schmidt F. Online activity boosts Germany's culture of political protest http://www.dw.de/online-activity-boostsgermanys-culture-of-political-protest/a-6148012-1 (Дата обращения: 23.09. 2012)

2 Жители общежитий протестуют против выселений // LB.ua/Общество. 22 декабря 2011.
}

инициированные Европейской комиссией по правам человека, неправительственными фондами и благотворительными организациями. По мнению бывшего Президента Европейского Союза Ж. Санте (1996 г.): «Сегодня есть необходимость в мобилизации населения. Очень важен диалог с людьми, и ничего не удается сделать без вовлечения «корней травы». Мы должны двигаться в сторону более активного гражданского участия» ${ }^{3}$. Реализация социальных программ Европейского Союза возлагается на исследовательские центры гражданских инициатив стран Центральной и Восточной Европы. Основными формами их деятельности становятся сравнительные исследования форм гражданского участия ${ }^{4}$, преимущественно посвященные анализу деятельности общественных организаций; проведение конференций, семинаров, тренингов и т.д. Показателем результативности деятельности центров становятся недели гражданского участия, включающие мероприятия, призванные повысить уровень политической культуры граждан, расширить их представления о способах и формах политической активности в условиях демократического государства. Так, неделя гражданского участия, проведенная в Киеве в ноябре 2011 г., охватила следующий круг проблем: политическая культура современного европейского сообщества, доступ к общественным услугам через социально-политические механизмы и возможность участия в общественной жиз-

\footnotetext{
${ }^{3}$ Active citizenship and community involvement: Getting to the roots. A discussion paper. European foundation fond. The improvement of living and working conditions, 1997.- P. 67.

${ }^{4}$ Например, подобные результаты исследования были изложены в фундаментальном труде: Атлас гражданских инициатив в Украине: опыт региональных партнеров программы «Гражданские инициативы в Восточной Европе» 2004-2007 гг. Чернигов: Центр гуманитарных технологий, 2008.- 114 с.
} 
ни мало представленных групп населения ${ }^{1}$. Несомненно, деятельность подобных центров гражданских инициатив свидетельствует о достаточно низкой активности европейского сообщества в вопросах политического участия, в том числе и на уровне соседской общины. Стремление публичной власти перераспределить полномочия на уровень территориального сообщества, предложив для этого соответствующие механизмы и ресурсное обеспечение, столкнулось с устойчивым неприятием подобных инициатив. Гораздо более ощутимых результатов удалось добиться на территориях, где потребности местного сообщества и интересы инициаторов благотворительных и социальных программ совпадали. В результате, на территории небольших школьных округов Греции появились родительские ассоциации, контролировавшие расходование средств школьного бюджета, оказывавшие бесплатные консультации по целому кругу вопросов, включая социальное обеспечение, здравоохранение, жилье, семейные проблемы ${ }^{2}$; в Португалии, а затем и во всех странах Европы, получили распространение клубы по месту жительства, призванные как объединить граждан, имеющих общие интересы, так и решать конкретные социальные проблемы на территории общины ${ }^{3}$.

Ответной реакцией французского общества на кризис, связанный со значительным потоком эмигрантов в начале 2000-х гг, и сопровождавшие его беспорядки, стала

\footnotetext{
${ }^{1}$ Европейская идея местной демократии http://svc.gov. ua/ru/news/view/caption/evropeyskaya-demokratiya (Дата обращения: 20.08.2012)

${ }^{2}$ Greek parent association http://greekparentsassociation. net/ (Дата обращения: 10.10.2012)

${ }^{3}$ Опыт европейских местных сообществ транслируется на переходные общества и государства «третьего мира». См. напр.: Community listeners' Clubs: Stepping stones for action in rural areas. N.Y.: Fao-dimitra, August 2011.—54 p.
}

попытка отдельных граждан сформировать добровольческие волонтерские организации, занимающиеся как решением социальных проблем, так и поиском необходимых для этого финансовых ресурсов. Так, в 2003 г. жители города Тулузы, создали ассоциацию жителей, состоящую преимущественно из молодых людей. Целью ее деятельности стала разработка социальных программ, касающихся освещения стоянок для автомобилей, очистки общественных территорий, установки телефонов-автоматов и т.д. Все программы были обсуждены на собраниях жителей и представлены в городскую администрацию, которая выделила необходимые средства и строительные материалы для их реализации ${ }^{4}$. На сегодняшний день количество членов данной организации составляет около 5000 человек и круг задач, стоящих перед ней постоянно расширяется. В отличие от большинства примеров общественной самоорганизации, опыт волонтерских организаций Франции свидетельствует о неограниченных возможностях гражданских инициатив в решении жизненно важных проблем развития территории.

С учетом разнообразия форм вторичной общественной самоорганизации в зарубежных странах, возможно, выделить следующие разновидности ассоциаций граждан по месту их жительства. Во-первых, группы взаимопомощи, создаваемые для решения общих проблем, волнующих всех членов группы (например, клубы по месту жительства, ассоциации родителей, престарелых и т.д.). В отличие от всех последующих объединений группы взаимопомощи ориентированы непосредственно на самостоятельную инициативу

\footnotetext{
${ }^{4}$ Szabo S. Basic facts about Volunteering in France http:// www.intergenerationes.eu/fileadmin/media/documents/ Konferenz_Doku/Case_Study_FranceBenevolat_EN.pdf (Дата обращения: 10.10.2012)
} 
членов местного сообщества по объединению усилий для достижения конкретного результата. С другой стороны, они зачастую возникают как реакция на предложения, исходящие от отдельных общественных организаций, что не позволяет оценивать их в качестве стихийной формы самоорганизации граждан. Во-вторых, группы, преследующие благотворительные цели (общественные консультативные центры, ассоциации по благоустройству микрорайона, оказанию помощи социально незащищенным слоям общества). Они характеризуются наличием бюджета, ограниченного финансовыми возможностями входящих в них субъектов (добровольцев). В-третьих, представительные группы и согласительные группы, в состав которых входят делегаты местных сообществ, представляющих ассоциации (советы) жителей. Агрегируя интересы соседских сообществ, группы пытаются довести их до сведения местной власти, зачастую сталкиваясь с необходимостью согласования противоречивых потребностей отдельных социальных групп. В-четвертых, группы давления или политического действия, которые прибегают как конвенциональным, так и неконвенциональным формам борьбы за собственные интересы. С одной стороны, данные группы способствуют объединению усилий представителей местного сообщества, провоцируя их на активные действия, с другой стороны, они зачастую являются средством лоббирования интересов определенных политических партий, политических и бизнес элит и т.д. В-пятых, добровольные (волонтерские) организации зачастую входящие в группы взаимопомощи и группы интересов. В отличие от предшествующих видов ассоциаций жителей волонтерские организации практически всегда создаются по инициативе национального или регионального благотворительного фонда, и финансируются также из бюджетов разного уровня.
Складывание разнообразных форм общественной самодеятельности, выражающих интересы определенных групп населения, актуализировало задачу поиска оптимальных способов их кооперативного взаимодействия с органами публичной власти, которые были вынуждены определить свое отношение к данным механизмам гражданского согласия и сотрудничества. Ответная реакция гражданского общества стала критерием эффективности реализации государственной и муниципальной политики. Так, по данным Фонда общинного развития в Великобритании в конце 2000-х гг. более $50 \%$ граждан участвуют в общественно полезной деятельности по месту жительства на безвозмездной основе, при этом, самостоятельно определяя ее формы и виды ${ }^{1}$. Отсутствие развитых горизонтальных коммуникаций, преобладание административно-бюрократической структуры зачастую приводило к складыванию своеобразной культуры гражданского противостояния, проявляющейся в неконвенциональных формах протеста.

Для постдемократического этапа развития общества протесты как способ выражения общественного мнения с помощью слов или действий, обусловленных конкретным событием или ситуацией, принимают различные формы, от индивидуальных заявлений до массовых демонстраций. Как правило, протестующие организуют акции протеста с целью повлиять на общественное мнение и политические институты, или осуществить прямые действия по изменению политической ситуации в государстве, на локальной территории ${ }^{2}$. Целевые установки подобных способов выражения общественного

\footnotetext{
${ }^{1}$ Working with Communities is a new resource providing help and signposting for your community organization http:// www.cdf.org.uk (Дата обращения: 12.08.2012)

${ }^{2}$ Robert A, Garton T. (eds.), Civil resistance and power politics: The experience of non-violent action from Gandhi to the present, Oxford: Oxford University press, 2009.- P. 194.
} 
мнения могут быть различными и зачастую ограничиваются отдельной сферой общественных отношений: политической, экономической религиозной, социальной или информационной. В отношении локальных сообществ может идти речь об использовании нескольких форм протеста, при этом, их особенностью является спонтанный характер и направленность на решение социальных проблем развития территории и лишь частично на политические цели и задачи. Протестное движение на территории проживания местных сообществ оценивается в качестве канала горизонтальной коммуникации, позволяющего общественному мнению определить свое отношение к инициативам политических институтов или отреагировать на изменения в структуре собственного территориального пространства.

В первую очередь необходимо выделить такие формы прямого действия как публичные демонстрации и митинги, направленные на решение жизненно важных проблем развития территории, преимущественно связанных с нарушением права граждан на окружающую среду, получение доступа к ресурсам, монополизацией отдельных отраслей промышленности и связи, а также с критическим состоянием местности после природных катастроф и стихийных событий. Так, 17 ноября 2012 г. в мексиканской деревне Crooked Tree прошел митинг протеста, на котором граждане потребовали лишения компании Белиз Audubon Society лицензии на право осуществления деятельности по охране окружающей среды, поскольку имеются факты несоблюдения интересов коренных жителей, для которых рыбная ловля является основным видом профессиональной деятельности ${ }^{1}$. В знак протеста против перебоев с подачей электроэнергии

${ }^{1}$ Crooked Tree Residents Demonstrate Against Audubon Society http://www.ctv3belizenews.com/ (Дата обращения: 01.12.2012) и дефицитом топлива после урагана Сэнди, жители Лонг-Айленда (Нью-Йорк) организовали 31 октября 2012 г. акцию протеста перед штаб-квартирой Long Island Power Authority $(\mathrm{LIPA})^{2}$. Отличительным свойством подобных акций протеста является косвенный характер самоорганизации граждан, поскольку использование своего права на активные действия напрямую зависит от актуализации определенных жизненных проблем или принятого политического решения.

Пикет как форма протеста, используется в случае необходимости собраться за пределами территории проживания жителей, для привлечения к проблеме широкого круга граждан. Подобные формы протеста широко распространены в крупных городах Великобритании ${ }^{3}$. В июле 2009 г., августе 2011 г. жители английского города Ньюгай (около 80 человек) выступили с публичным протестом против асоциальных форм поведения отдельных групп граждан, которые отрицательно сказываются на безопасности населения, а также свидетельствуют о бездействии городского совета ${ }^{4}$. В условиях глобального экономического кризиса пикеты зачастую рассматриваются в качестве единственного средства выразить свое отношение к массовой безработице, сокращению уровня доходов и другим социальным проблемам. Так, в сентябре 2012 г. жители города Оттава (Канада) собрались в парке Конфедерации на акцию протеста с требованием прекратить сокращение сотрудников крупнейшими

\footnotetext{
${ }^{2}$ Long Island residents in New York protest against power outage http://www.presstv.ir/detail/2012/11/11/271543/ ny-residents-protest-at-power-outages/ (Дата обращения: 02.12.2012)

${ }^{3}$ Matt S. Critical crackdown / S. Matt // London: The Guardian. Retrieved. May 22. 2010.

${ }^{4}$ Town residents in drink protest http://news.bbc.co.uk/2/hi/ uk_news/england/cornwall/8172094.stm (Дата обращения: 20.09.2012)
} 
предприятиями, а также повлиять на планы сокращения еще 19000 рабочих мест для экономии 5,2 млрд. долларов ${ }^{1}$. Распространенной формой пикетирований (особенно в небольших населенных пунктах) становятся так называемые «улицы протестующих», позволяющие вовлечь в акцию максимально большое количество участников.

Процессы информатизации, охватившие мировое сообщество, оказывают непосредственное воздействие на выбор форм и механизмов протестной активности местного сообщества. Блоги и социальные сети стали эффективными инструментами для регистрации проявлений протеста и недовольства. Специалисты Оксфордского университета в 2011-2012 гг. провели глобальное исследование роли социальных сетей в формировании общественного мнения населения Испании и их влияния на процессы протестной активности. Основная масса сообщений была ориентирована на организацию целой серии акций протеста на локальных территориях, направленных против предоставления государственных льгот крупнейшим монополиям, а также ухудшения социально-экономической ситуации, вызванной экономическим кризисом ${ }^{2}$. Его результатом стал вывод о необходимости внимательного отношения политических институтов к механизмам сетевой коммуникации, поскольку именно в сети Интернет создается уникальная ситуация формирования общественного мнения без личностного количества пользователей, которая зачастую преобразуется в акции протеста нековенциональной формы. С другой стороны, отсутствие территориальной обусловленности

\footnotetext{
${ }^{1}$ PSAC rallies to protest continued staff reductions http:// www.ottawacitizen.com/PSAC + rallies + protest + continued + staff+reductions/7248964/story.html (Дата обращения: 03.12.2012)

${ }^{2}$ The role of social media in protests http://www.ox.ac.uk/ media/news_stories/2011/111612.html (Дата обращения: 03.12.2012)
}

общности интересов, ограниченность условий для совместных действий приводит к сужению потенциала сетевых механизмов реализации политической активности местного сообщества.

В значительно большей степени проявления политической самоорганизации локального сообщества становятся очевидными при наличии развитой сети общественных организаций, осуществляющих целенаправленную работу с населением. Общественные некоммерческие организации, претендуя на роль посредника в отношениях между обществом и политическими институтами, не получая необходимой поддержки и ресурсов, оказываются перед необходимостью вовлечения населения в политические процессы. Пример Франции, оказавшейся в 2006 г. перед угрозой серьезного политического кризиса, обусловленного молодежным движением протеста против пенсионной реформы и реформы в сфере образования, показал, что на современном этапе развития государства «... невозможно строить отношения между властью и народом в обход структур гражданского общества. Чтобы наладить такой диалог, необходимо разграничение компетенции выборных органов власти, где представлены все граждане, и неправительственные организации гражданского общества, выражающие интересы отдельных социальных групп»³. Следствием институционального оформления ассоциаций по месту жительства на протяжении 2000-х гг. стало создание некоммерческих общественных организаций (НКО), фондов, партнерств, ставящих перед собой четко определенные цели и добивающиеся их достижения посредством объединения усилий местного сообщества, предпринимателей и органов власти. В отличие

\footnotetext{
3 Рубинский Ю. И. Культура гражданского противостояния / Ю.И. Рубинский / Россия в глобальной политике. Т. 4. № 2. Март-Апрель. 2006.- С. 173. См. подр.: Understanding european movements. New social movements, global justice struggles, anti-austerity protest / Ed. by C. F. Fominaya, L. Cox. N.Y.: Routledge, 2012-304 p.
} 
от территориальных ассоциаций сфера деятельности НКО касалась широкого круга проблем, преимущественно, социальной направленности. Выбор методов достижения целей также отличался разнообразием, но ключевое значение приобретала пропаганда идей общественной самодеятельности как средства решения вопросов местного значения. Данную форму гражданской самодеятельности мы относим ко второй группе - вторичной самоорганизации.

По отношению к процессам самоорганизации местного сообщества, возможно, выделить две группы общественных организаций: общинные и городские, действующие в пределах соответствующей локальной территории. Для современных государств в наибольшей степени характерны следующие виды организаций: сообщества-действия, созданные для совместного решения проблем; объединения в области здравоохранения, образования; сообщества личностного роста, социального обеспечения и помощи нуждающимся ${ }^{1}$. Ключевой задачей подобных общественных организаций становится поддержка инициатив местных сообществ или создание условий для их коллективного действия. По мнению одного из организаторов местного сообщества Хизер Бут, «Сообщество является средством организации построения публичной власти путем вовлечения избирателей в процесс выявления проблем; выявление людей и структур, которые могут принять необходимые решения посредством переговоров или с помощью конфронтации и давление; создание демократического учреждения, представляющего интересы избирателей округа» ${ }^{2}$.

\footnotetext{
${ }^{1}$ Szakos K.L., Szakos J. We make change: community organizers talk about what they do - and why. Nashville: Vanderbilt University Press, 2007 - P. 231.

${ }^{2}$ Beckwith D., Lopez C. Community Organizing: People Power from the Grassroots Center for Community Change http://comm-org.wisc.edu/papers97/beckwith.htm (Дата обращения: 02.12.2012)
}

Зачастую общественные организации выходят за рамки политических и правовых механизмов, предоставленных им политической властью, пытаясь использовать конвенциональные, но свойственные скорее политическим институтам методы отстаивания собственных интересов. Так, общественная организация с говорящим названием «Жители штата Мэн против тухлой сделки» пытаясь не допустить легализацию азартных игр на территории штата, используют такие формы борьбы как агитация, сайт в Интернете и иные политические технологии. Свою цель организация формулирует достаточно четко: «Основной задачей организации сейчас является противостояние ожидаемому одобрению гемблинга на законодательном собрании и вынесение этого вопроса на референдум»³. Подобные средства давления на политическую власть оказываются весьма эффективными только при условии наличия развитой сетевой коммуникации, охватывающей все существующие информационные каналы.

В целях поддержки соседских сообществ на средства государственного и местного бюджетов организуются специализированные некоммерческие институты (фонды, корпорации). Одной из наиболее крупных выступает Federal corporation for National service, занимающаяся распределением краткосрочных и долгосрочных грантов для развития соседских сообществ ${ }^{4}$. Вопросы строительства и эксплуатации жилья для малоимущих граждан находятся в компетенции Local initiatives support corporation, работающей совместно с местными властями и ассоциациями гра-

\footnotetext{
${ }^{3}$ Организация «Жители штата Мэн против тухлой сделки» отпугнут легализацию гемблинга названием http:// activebet.ru/news/491 (Дата обращения: 12.10.2012)

${ }^{4}$ http://www.nationalservice.gov/ (Дата обращения: 20.04.2012)
} 
ждан ${ }^{1}$. Особое значение приобретают образовательные центры, занимающиеся повышением квалификации и обучением актива местных сообществ (например, Mid — West Academy в Чикаго) $)^{2}$.

Отдельного внимания в оценке современного содержания и форм гражданской самоорганизации имеет институт социальных технологов (организаторов), созданный в США и получивший широкое распространение в зарубежных государствах. В отличие от предыдущих форм общественной самодеятельности, данная форма отличается формально-институциональным характером, поскольку деятельность технологов финансируется из местного бюджета или бюджета международных общественных организаций. Целью организатора является создание условий для вовлечения населения в решение ключевых вопросов жизнедеятельности посредством использования современных психолого-педагогических и политико-социальных технологий ${ }^{3}$. В европейской практике работа специалиста-технолога направлена на создание соседских центров (объединений) жителей, имеющих профильную направленность на решение конкретной проблемы (например, центры по борьбе с преступностью, за озеленение парковой зоны и т.д.). В структуру центров входят не только специалисты-технологи, но и психологи, педагоги, добровольцы (волонтеры) из числа наиболее активных членов местного сообщества.

Одной из наиболее известных организаций граждан по месту их жительства является шведская организация «Дерево», объединяющая соседские ассоциации микрорайона

\footnotetext{
${ }^{1}$ http://www.lisc.org/ (Дата обращения: 20.04.2012)

2 http://www.midwestacademy.com/ (Дата обращения: 20.04.2012)

${ }^{3}$ Kahn J. Creative Community Organizing: A Guide for Rabble-Rousers, Activists, and Quiet Lovers of Justice. N.Y.: Berrett-Koehler, 2010._- P. 37.
}

Бриккебакен г. Эребру. Инициатива по ее созданию исходила от специалистов-организаторов, финансируемых из бюджета Совета микрорайона. На момент создания в 1987 г. «Дерево» включало 5 общественных организаций, на сегодняшний день более 35 (2011 г.). Целью ее деятельности стало вовлечение жителей в различные социокультурные мероприятия, организация их досуга, а также совместное решение вопросов благоустройства территории ${ }^{4}$.

Помимо отдельных специалистов, работающих в сфере социальных технологий, сформированы национальные объединенные институты и организации, специализирующиеся на создании условий для развития соседских сообществ. Как правило, они функционируют на общегосударственном или региональном уровнях власти. Агентство по борьбе с бедностью Ирландии (Combat poverty agency) являясь членом международной организации - Объединенного европейского бюро социального развития, ставит перед собой задачу стимулирования активности местных сообществ через искусство ${ }^{5}$. Венгерская ассоциация развития соседских сообществ (ВАРCC) участвует в организации совместного сотрудничества между сельскими населенными пунктами. Технологии реализации поставленной цели предполагают проведение анкетирования жителей, пропагандистские мероприятия (выставки, тренинги, гражданские форумы, семинары $)^{6}$.

Исследование причин и проявлений политической активности граждан на уровне

\footnotetext{
${ }^{4}$ См. подр.: Reesvan W. Rodriges F. (n.d.). Participation in the third poverty programmed. Benelux\&Portuguese Units for research and development, 2008.- P. 75.

5 http://www.combatpoverty.ie/ (Дата обращения: 20.03.2012)

${ }^{6} \mathrm{http}: / /$ www.ge.com/hu/en/company/factsheet_hu_en.html (Дата обращения: 13.05.2012)
} 
местных сообществ оказывается необходимым средством получения информации о возможных формах их политического поведения в условиях социально-экономических, национально-культурных противоречий, нарушения баланса интересов государства и общества, глобального экономического кризиса. Определяющее значение в данном процессе придается местной традиции, закладывающей основы политического самоопределения населения ${ }^{1}$. Соседские сообщества оказались достаточно динамичной сферой приложения инициатив публичной власти, поскольку потребовали изменения направленности политических решений в зависимости от первоначальной реакции их участников. Наиболее показательным примером совершенствования практики сотрудничества местной власти с ассоциациями жителей стала деятельность Центров гражданского участия, ориентированных на поддержку движений волонтерства, решение проблем занятости населения и т. д. ${ }^{2}$

Первоначально взаимоотношения муниципалитетов с ассоциациями жителей основывались на предоставлении дополнительных средств для эксплуатации многоэтажных зданий, находящихся в собственности органов местной власти, в зависимости от степени активности организаций жителей; выделении специальных помещений для проведения собраний жителей; создании дополнительных условий для проявлений гражданской активности. Следствием целенаправленной позиции муниципалитетов по поддержанию высокого уровня гражданской активности жителей стало создание сети ор-

\footnotetext{
${ }^{1}$ Foster C.C., Louie J. Grassroots action and learning for social change: evaluating community organizing. Blueprint Research \& Design, Inc., 2010 - P. 1-15.

2 Достаточно успешным опытом решения проблем территории является деятельность калифорнийского центра гражданских инициатив (США): [Режим доступа] http://californiacenter.org/opportunities/ (Дата обращения: 20.03.2012)
}

ганизаций квартиросъемщиков, выступавших с совершенно конкретными требованиями, как на собраниях, так и на политических акциях ${ }^{3}$. Фактически, речь шла о готовности местных сообществ, получивших поддержку местной власти, претендовать на решение не только проблем микрорайона, но и всего муниципалитета. Осознание этого процесса потребовало его комплексной оценки и перехода на новый уровень организации местного сообщества. По справедливому замечанию министра местного управления Шотландии, «одних консультаций с жителями недостаточно. Необходимо там, где это возможно, непосредственное вовлечение квартиросъемщиков в управление и оказание жилищных услуг (обслуживание жилого фонда) ... Это означает разработку настоящего контроля за политикой и ресурсами на локальном уровне, создание более четких целевых и отвечающих требованиям жителей программ, которые на самом деле приведут к усилению ответственности и демократии» ${ }^{4}$.

Для повышения уровня вовлеченности местного сообщества в социально-политический процесс в европейских государствах используются ресурсы не только общественных некоммерческих организаций, но и коалиций ассоциаций жителей или зонтичные организации, объединявшиеся по принципу территориальной близости к ведущему объединению5. С точки зрения местной власти подобные коалиции (в Великобритании федерации) становятся механизмом сотрудничества с местным

\footnotetext{
${ }^{3}$ Наибольший резонанс получили кампании: «Право на тепло», «Против влажности в домах», против закона о квартплате, загрязнений окружающей среды корпорациями и т.д.

${ }^{4}$ Organizing around hot issues // Vancouver Community Network. Retrieved. № 8. 2012 - P. 24.

${ }^{5}$ Patapas A., Maculevič J. Seniūnaitijų organizavimo ir veiklos probleminiai aspektai / A. Patapas, J. Maculevič / Public policy and administration. 2011. T. 10. № 3 / 2011. Vol. 10. № 3.- - P. 410.
} 
сообществом, преодоления узколокальных интересов общины и перехода на новый уровень публичных отношений. К числу подобных федераций в Великобритании относятся: Федерация ассоциаций квартиросъемщиков и жителей районов Хаммерсмит и Фулхэм (Hammersmith and Fulham Federation of tenants and residents associations - HAFFTRA) ${ }^{1}$, Федерация организаций квартиросъемщиков и жителей графства Киркли (Kirk lees Federation of Tenants and Residents associations - KFTRA) ${ }^{2}$, Национальная ассоциация местных советов (NALC) ${ }^{3}$, и др. Отличительным свойством подобных федераций является их способность организовать взаимодействия с местными органами власти, общественными объединениями, компаниями, используя сложившиеся договорные отношения, а также привлекать благотворительные организации и волонтеров для решения возникающих проблемных вопросов. Соседские сообщества, объединенные в ассоциации жителей, и входящие в состав коалиций, как правило, решают две группы проблем: борьба с деградацией микрорайонов, населенных социально незащищенными слоями общества, и сохранение привлекательности престижных («нормальных») территорий.

Соседские сообщества на современном этапе развития государства и общества выступают в качестве способа выражения индивидуального и общественного мнения населения. Особенностью последних десяти лет стало появление ассоциаций для решения одной конкретной проблемы, наряду с существованием объединений широкого спектра действий. Подавляющее большинство ассоциаций жителей пытаются использовать имеющиеся у них вертикальные каналы

\footnotetext{
${ }^{1} \mathrm{http}: /$ hafftra.co.uk/hafnep/hafnep-index.html (Дата обращения: 20.03.2012)

${ }^{2}$ http://www.kftra.net/ (Дата обращения: 20.03.2012)

${ }^{3} \mathrm{http}: / /$ www.nalc.gov.uk/About_NALC/About_NALC.aspx (Дата обращения: 19.06.2012)
}

коммуникации, выдвигать своих кандидатов в местные органы власти с целью увеличения своего влияния на общественное мнение, заниматься пропагандой своих целей и принципов, организовывать инициативные группы из числа добровольцев ${ }^{4}$. Зачастую в целях получения возможности самостоятельно участвовать в политическом процессе (выборах в районные советы) ассоциации приобретают статус политических партий. В отличие от некоммерческих организаций ассоциации жителей, как правило, не имеют постоянного членства, открыты для всех местных жителей, проживающих в определенной области, таких как жилой комплекс, жилой дом в пригороде или избирательного округа, что позволяет им использовать горизонтальные механизмы коммуникации: проведение совместных мероприятий (дискуссий, клубов по месту жительства, дебатов, круглых столов), подготовка коллективных обращений, заключение договоров с органами местной власти и общественными организациями и т. д. В частности, на территории Венгрии вопросы развития соседских сообществ находятся в компетенции Венгерской ассоциации развития местных сообществ (ВАРСС), созданной в 1989 г. по инициативе правительства. В 2011 г. Ассоциация местных властей района Mecsekalja обратилась в ВАРСС с просьбой провести социологический опрос на тему готовности граждан участвовать в решении социально-поли-

\footnotetext{
${ }^{4}$ Так, ассоциации жителей Нью-Вестминстера (Канада) представляют собой неполитические общественные группы, заинтересованные в решении отдельных вопросов развития территории. Одной из задач ассоциаций является реализация совместных проектов с городским муниципалитетом, касающихся реализации гражданских инициатив и решения социальных вопросов. См. подр.: $\mathrm{http} / / /$ www.newwestcity.ca/about the city/living in new westminster/residents_associations.php (Дата обращения: 05.12.2012)
} 
тических вопросов развития территории, по результатам которого был составлен план мероприятий. Основными формами деятельности ассоциации стали: публичные обсуждения важнейших вопросов развития территории, интервью, анкетирования жителей, тренинги, гражданские форумы ${ }^{1}$. Несмотря на универсальность используемых технологий работы с населением, удалось добиться положительных результатов (повышение общего уровня политической активности, создание собрания представителей при местных органов власти, появление самостоятельных гражданских инициатив), поскольку принималась во внимание специфика отдельной локальной территории ${ }^{2}$. С другой стороны, отмечается и другая тенденция - привлечение разнообразных технологий работы с населением лишает ассоциации жителей необходимых условий для проявлений стихийной самоорганизации, задавая четкие ориентиры при выборе механизмов проявлений политической активности граждан.

Современная зарубежная практика использования самоорганизационных механизмов свидетельствует о преобладании вертикальных, формальных коммуникационных каналов, источником которых выступают органы публичной власти и их должностные лица. Соседское сообщество, заняв выжидательную позицию, оказалось фактически выключено из процесса принятия политических решений на локальной

\footnotetext{
${ }^{1} \mathrm{http}: / /$ www.kka.hu/weblapok.nsf/dd5cab6801f1723585256 474005327c8/db3a7a554b84db62c1256a7a00629336 (Дата обращения: 05.12.2012)

2 Данные выводы получены исходя из анализа официального годового отчета ассоциации за 2011 г., расположенного на официальном сайте Ассоциации: http:/ www.ceecn.net/best/43-hungary/188-hungarian-associationfor-community-development.html (Дата обращения: 20.03.2012)
}

территории. Наличие отдельных примеров непосредственного волеизъявления граждан и самостоятельного выбора соответствующих форм политической активности, не меняет общих тенденций развития прямой демократии в зарубежной практике. Самоорганизационные возможности сообщества, включенные в институциональные формы, привели к перманентному конфликту, выражением которого стали новые альтернативные социальные движения, формы политического протеста, недоверие (или апатия) основной массы населения к инициативам, исходящим от органов публичной власти (так называемый «кризис участия»). Преобладание вторичной самоорганизации, прямое вмешательство в процесс самодеятельности местных сообществ со стороны, как институтов публичной власти, так и профессионального сообщества политтехнологов (организаторов) окончательно разрушило потребность населения в самостоятельном волеизьявлении на уровне местной власти. Первоначальные усилия местных сообществ (ассоциаций, объединений) по формированию сетевых механизмов вовлечения граждан в решение проблем развития локальной территории оказались включены в механизмы связей с общественностью органов местной власти и разнообразных некоммерческих организаций. Вторичная самоорганизация в зарубежных государствах приобретает свойство ключевого инструмента объединения членов местного сообщества для совместной деятельности и формирования единого общественного мнения, средства его солидаризации (координации), формирования сетевых структур, способных стать источником развития гражданского общества, основанного на самоорганизации как средстве выражения его собственных интересов и потребностей. 


\section{Библиография}

1. Атлас гражданских инициатив в Украине: опыт региональных партнеров программы «Гражданские инициативы в Восточной Европе» 2004-2007 гг. Чернигов: Центр гуманитарных технологий, 2008.- 114 с.

2. Бирюков С. Швейцарский бастион. Прямая демократия против толерантности и мультикультурализма / С. Бирюков // Агентство политических новостей. 20.04.2009 г.

3. Вагин В. Социология города / В. Вагин http: www.gumer.info/bibliotek_Buks/Sociolog/ Vagin/04/php (Дата обращения: 25.12.2012)

4. Грамши А. Избранные произведения: [пер. с итал.] / [Под общ. ред. И. В. Григорьевой и др.; Вступит. статья Г.П. Смирнова; Примеч. И. В. Григорьевой, К. Ф. Мизиано].- М.: Политиздат, 1980.422 c.

5. Европейская идея местной демократии Режим доступа: http://svc.gov.ua/ru/news/ view/caption/evropeyskaya-demokratiya (Дата обращения: 20.08.2012)

6. Жители общежитий протестуют против выселений // LB.ua/Общество. 22 декабря 2011.

7. Заокеанский опыт. Защита жилищных прав // ТриД (электронный журнал). 2009. № 2.

8. Заргарян Р. Новые альтернативные движения в Европе: кто они и чего хотят? / Р. Заргарян // Analitica. 25.10.2011.

9. Кокарев И.Е. Местные сообщества и местное самоуправление: технологии участия / И. Е. Кокарев. М.: МОНФ, 2007. Вып. 63. - $208 \mathrm{c}$.

10. Макогон Т.И. Местные сообщества и гражданские инициативы / Т.И. Макогон // Вестник ТГПУ. 2011. № 11 (113).

11. Могилевская Ю. «Кузница кадров по американски» (сент. 2012 г.) http: gkhprim. ru/news/interview/kuznitsa_kadrov_poamerikanski/ (Дата обращения: 24.12.2012)
12. Сейм выполнил требование Ассоциации жителей денацдомов и отозвал бесчеловечные поправки // Publica.LV. 5 апреля 2012 г.

13. Active citizenship and community involvement: Getting to the roots. A discussion paper. European foundation fond. The improvement of living and working conditions, 1997.

14. Brown R. The emergence of voluntary associations in Massachusetts, 1760-1830 // Journal of voluntary association research. 1973. № 2 (2).- - P. 64-73.

15. Chigbu U.E. Village renewal as an instrument of rural development: evidence from Wryarn, Germany // Community Development. № 43 (2). - P. 209-224.

16. Civic engagement in American democracy / Ed. By T. Skocpol, M. Florina. Washington: Brookings institution press, 1999.

17. Community development challenge report / Community development foundation for communities and local government http://www. cdf.org.uk/SITE/UPLOAD/DOCUMENT/ communitydevelopmentchallenge.pdf (Дата обращения: 20.09.2012)

18. Community listeners' Clubs: Stepping stones for action in rural areas. N.Y.: Fao-dimitra, August 2011. - 54 p.

19. Cornell cooperative extension Режим доступа: http://www.cce.cornell.edu/Pages/Default. aspx (Дата обращения: 12.11.2012)

20. Crooked Tree Residents Demonstrate Against Audubon Society http://www.ctv3belizenews. com/ (Дата обращения: 01.12.2012)

21. Ferguson R.F., William T.D., eds., Urban Problems and Community Development. Brookings Institution Press, 1999.

22. Foster C. C., Louie J. Grassroots action and learning for social change: evaluating community organizing. Blueprint Research \& Design, Inc., 2010.

23. Harris K. Isn't all community development asset-based? // Guardian piece. 23 July. 2011. 


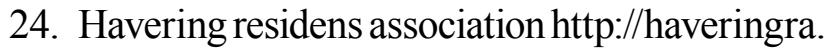
org.uk/ (Дата обращения: 20.12.2012

25. Greek parent association http:// greekparentsassociation.net/ (Дата обращения: 10.10.2012)

26. Kahn J. Creative Community Organizing: A Guide for Rabble-Rousers, Activists, and Quiet Lovers of Justice. N.Y.: Berrett-Koehler, 2010.

27. Residents Associations http://www.melton. gov.uk/housing/resident_involvement/ residents_associations.aspx (Дата обращения: $24.0 \overline{9} .2012$ )

28. Initiatives and funding programs Режим доступа: http://www.nysegov.com/citGuide. cfm? superCat $=396 \&$ cat $=404 \&$ content $=$ main (Дата обращения: 12.11.2012)

29. Long Island residents in New York protest against power outage http:/www.presstv. ir/detail/2012/11/11/271543/ny-residentsprotest-at-power-outages/ (Дата обращения: 02.12.2012)

30. Neighborhood and Community Relations (NCR) Режим доступа: http://www. minneapolismn.gov/ncr/index.htm (Дата обращения: 24.12.2012)

31. Neighborhood and community service Режим доступа: http://www.ncsmobile.org/about.php (Дата обращения: 12.11.2012)

32. Neighborhood and community development Режим доступа: http://www.austintexas.gov/ department/housing/media (Дата обращения: 12.11.2012)

33. Neighborhood community foundation Режим доступа: http://neighborhood-community.org/ (Дата обращения: 12.11.2012)

34. Neighborhood housing services of New York Режим доступа: http:/www.nhsnyc.org/en/ about-us (Дата обращения: 12.11.2012)

35. Organizing around hot issues // Vancouver Community Network. Retrieved. № 8. 2012.

36. Reesvan W. Rodriges F. (n.d.). Participation in the third poverty programmed.
Benelux\&Portuguese Units for research and development, 2008.

37. Robert A, Garton T. (eds.), Civil resistance and power politics: The experience of non-violent action from Gandhi to the present, Oxford: Oxford University press, 2009.

38. Understanding european movements. New social movements, global justice struggles, anti-austerity protest / Ed. by C. F. Fominaya, L. Cox. N.Y.: Routledge, 2012-304 p.

39. Szakos K. L., Szakos J. We make change: community organizers talk about what they do - and why. Nashville: Vanderbilt University Press, 2007-241 p.

40. Schmidt F. Online activity boosts Germany's culture of political protest http://www.dw.de/ online-activity-boosts-germanys-culture-ofpolitical-protest/a-6148012-1 (Дата обращения: 23.09. 2012)

41. Szabo S. Basic facts about Volunteering in France http://www.intergenerationes.eu/ fileadmin/media/documents/Konferenz Doku/Case_Study_FranceBenevolat_EN.pdf (Дата обращения: 10.10.2012)

42. Taylor V., Barr A., West A. Signposts to community development foundation. N.Y., 2000.

43. Working with Communities is a new resource providing help and signposting for your community organization http:// www.cdf.org.uk (Дата обращения: 12.08.2012)

44. The role of social media in protests http://www. ox.ac.uk/media/news_stories/2011/111612. html (Дата обращения: 03.12.2012)

45. [Электронный ресурс] Режим доступа: http: www.euroalter.com/ppp/ (Дата обращения: 20.09.2012)

46. [Электронный ресурс] Режим доступа: http://www. iri-europe.org (Дата обращения: 13.12.2012)

47. http://www.nationalservice.gov/ (Дата обращения: 20.04.2012) 
48. http://www.lisc.org/ (Дата обращения: 20.04.2012)

49. http://www.midwestacademy.com/ (Дата обращения: 20.04.2012)

50. [Режим доступа] http://californiacenter.org/ opportunities/ (Дата обращения: 20.03.2012)

51. http://hafftra.co.uk/hafnep/hafnep-index.html (Дата обращения: 20.03.2012)

52. http://www.kftra.net/ (Дата обращения: 20.03.2012)

53. http://www.newwestcity.ca/about_the_city/ living_in_new_westminster/residents associations.php (Дата обращения: 05.12.2012)

54. http://www.kka.hu/weblapok.nsf/dd5cab68 01f1723585256474005327c8/db3a7a554b84 db62c1256a7a00629336 (Дата обращения: 05.12.2012)

55. http://www.ceecn.net/best/43-hungary/188hungarian-association-for-communitydevelopment.html (Дата обращения: 20.03.2012)

\section{References (transliterated)}

1. Atlas grazhdanskikh initsiativ v Ukraine: opyt regional'nykh partnerov programmy «Grazhdanskie initsiativy v Vostochnoi Evrope» 2004-2007 gg. Chernigov: Tsentr gumanitarnykh tekhnologii, 2008.- $114 \mathrm{~s}$.

2. Biryukov S. Shveitsarskii bastion. Pryamaya demokratiya protiv tolerantnosti i mul'tikul'turalizma / S. Biryukov // Agentstvo politicheskikh novostei. 20.04.2009g.

3. Vagin V. Sotsiologiya goroda / V. Vagin http: www.gumer.info/bibliotek Buks/ Sociolog/Vagin/04/php (Data obrashcheniya: 25.12.2012)

4. Gramshi A. Izbrannye proizvedeniya: [per. s ital.] / [Pod obshch. red. I. V. Grigor'evoi i dr.; Vstupit. stat'ya G. P. Smirnova; Primech. I. V. Grigor'evoi, K. F. Miziano].- M.: Politizdat, 1980.- $422 \mathrm{~s}$.
5. Evropeiskaya ideya mestnoi demokratii Rezhim dostupa: http://svc.gov.ua/ru/news/ view/caption/evropeyskaya-demokratiya (Data obrashcheniya: 20.08.2012)

6. Zhiteli obshchezhitii protestuyut protiv vyselenii // LB.ua/Obshchestvo. 22 dekabrya 2011.

7. Zaokeanskii opyt. Zashchita zhilishchnykh prav // TriD (elektronnyi zhurnal). 2009. № 2.

8. Zargaryan R. Novye al'ternativnye dvizheniya v Evrope: kto oni i chego khotyat? / R. Zargaryan // Analitica. 25.10.2011.

9. Kokarev I. E. Mestnye soobshchestva i mestnoe samoupravlenie: tekhnologii uchastiya / I. E. Kokarev. M.: MONF, 2007. Vyp. 63.- $208 \mathrm{~s}$.

10. Makogon T. I. Mestnye soobshchestva i grazhdanskie initsiativy / T. I. Makogon // Vestnik TGPU. 2011. № 11 (113).

11. Mogilevskaya $\mathrm{Yu}$. «Kuznitsa kadrov po amerikanski» (sent. 2012 g.) http: gkhprim. ru/news/interview/kuznitsa_kadrov_poamerikanski/ (Data obrashcheniya: 24.12.2012)

12. Seim vypolnil trebovanie Assotsiatsii zhitelei denatsdomov i otozval beschelovechnye popravki // Publica.LV. 5 aprelya 2012 g.

13. Active citizenship and community involvement: Getting to the roots. A discussion paper. European foundation fond. The improvement of living and working conditions, 1997.

14. Brown R. The emergence of voluntary associations in Massachusetts, 1760-1830 // Journal of voluntary association research. 1973. № 2 (2).- - P. 64-73.

15. Chigbu U.E. Village renewal as an instrument of rural development: evidence from Wryarn, Germany // Community Development. № 43 (2).- R. 209-224.

16. Civic engagement in American democracy / Ed. By T. Skocpol, M. Florina. Washington: Brookings institution press, 1999.

17. Community development challenge report / Community development foundation for 
communities and local government http://www. cdf.org.uk/SITE/UPLOAD/DOCUMENT/ communitydevelopmentchallenge.pdf (Data obrashcheniya: 20.09.2012)

18. Community listeners' Clubs: Stepping stones for action in rural areas. N.Y.: Fao-dimitra, August 2011. - 54 p.

19. Cornell cooperative extension Rezhim dostupa: http://www.cce.cornell.edu/Pages/ Default.aspx (Data obrashcheniya: 12.11.2012)

20. Crooked Tree Residents Demonstrate Against Audubon Society http://www.ctv3belizenews. com/ (Data obrashcheniya: 01.12.2012)

21. Ferguson R. F., William T. D., eds., Urban Problems and Community Development. Brookings Institution Press, 1999.

22. Foster C. C., Louie J. Grassroots action and learning for social change: evaluating community organizing. Blueprint Research \& Design, Inc., 2010.

23. Harris K. Isn't all community development asset-based? // Guardian piece. 23 July. 2011.

24. Havering residens association http:// haveringra.org.uk/ (Data obrashcheniya: 20.12.2012

25. Greek parent association http:// greekparentsassociation.net/ (Data obrashcheniya: 10.10.2012)

26. Kahn J. Creative Community Organizing: A Guide for Rabble-Rousers, Activists, and Quiet Lovers of Justice. N.Y.: Berrett-Koehler, 2010.

27. Residents Associations http://www.melton.gov. uk/housing/resident_involvement/residents associations.aspx (Data obrashcheniya: 24.09.2012)

28. Initiatives and funding programs Rezhim dostupa: http://www.nysegov.com/citGuide. cfm? superCat $=396 \&$ cat $=404 \&$ content $=$ main (Data obrashcheniya: 12.11.2012)

29. Long Island residents in New York protest against power outage http://www.presstv.ir/ detail/2012/11/11/271543/ny-residents-protest- at-power-outages/ (Data obrashcheniya: 02.12.2012)

30. Neighborhood and Community Relations (NCR) Rezhim dostupa: http://www. minneapolismn.gov/ncr/index.htm (Data obrashcheniya: 24.12.2012)

31. Neighborhood and community service Rezhim dostupa: http://www.ncsmobile.org/about.php (Data obrashcheniya: 12.11.2012)

32. Neighborhood and community development Rezhim dostupa: http://www.austintexas. gov/department/housing/media (Data obrashcheniya: 12.11.2012)

33. Neighborhood community foundation Rezhim dostupa: http://neighborhood-community.org/ (Data obrashcheniya: 12.11.2012)

34. Neighborhood housing services of New York Rezhim dostupa: http://www.nhsnyc.org/en/ about-us (Data obrashcheniya: 12.11.2012)

35. Organizing around hot issues // Vancouver Community Network. Retrieved. № 8. 2012.

36. Reesvan W. Rodriges F. (n.d.). Participation in the third poverty programmed. Benelux\&Portuguese Units for research and development, 2008.

37. Robert A, Garton T. (eds.), Civil resistance and power politics: The experience of non-violent action from Gandhi to the present, Oxford: Oxford University press, 2009.

38. Understanding european movements. New social movements, global justice struggles, anti-austerity protest / Ed. by C. F. Fominaya, L. Cox. N.Y.: Routledge, 2012-304 p.

39. Szakos K. L., Szakos J. We make change: community organizers talk about what they do - and why. Nashville: Vanderbilt University Press, 2007-241 r.

40. Schmidt F. Online activity boosts Germany's culture of political protest http://www. dw.de/online-activity-boosts-germanysculture-of-political-protest/a-6148012-1 (Data obrashcheniya: 23.09. 2012) 
41. Szabo S. Basic facts about Volunteering in France http://www.intergenerationes.eu/ fileadmin/media/documents/Konferenz Doku/Case_Study_FranceBenevolat_EN.pdf (Data obrashcheniya: 10.10.2012)

42. Taylor V., Barr A., West A. Signposts to community development foundation. N.Y., 2000.

43. Working with Communities is a new resource providing help and signposting for your community organization http://www.cdf.org. uk (Data obrashcheniya: 12.08.2012)

44. The role of social media in protests http://www. ox.ac.uk/media/news_stories/2011/111612. html (Data obrashcheniya: 03.12.2012)

45. Rezhim dostupa: http: www.euroalter.com/ ppp/ (Data obrashcheniya: 20.09.2012)

46. Rezhim dostupa: http://www. iri-europe.org (Data obrashcheniya: 13.12.2012)

47. http://www.nationalservice.gov/ (Data obrashcheniya: 20.04.2012)
48. http://www.lisc.org/ (Data obrashcheniya: 20.04.2012)

49. http://www.midwestacademy.com/ (Data obrashcheniya: 20.04.2012)

50. http://californiacenter.org/opportunities/ (Data obrashcheniya: 20.03.2012)

51. http://hafftra.co.uk/hafnep/hafnep-index.html (Data obrashcheniya: 20.03.2012)

52. http://www.kftra.net/ (Data obrashcheniya: 20.03.2012)

53. http://www.newwestcity.ca/about_the_city/ living_in_new_westminster/residents_ associations.php (Data obrashcheniya: 05.12.2012)

54. http://www.kka.hu/weblapok.nsf/dd5cab6801f17 23585256474005327c8/db3a7a554b84db62c1256 a7a00629336 (Data obrashcheniya: 05.12.2012)

55. http://www.ceecn.net/best/43-hungary/188hungarian-association-for-communitydevelopment.html (Data obrashcheniya: 20.03.2012) 